\title{
PRIMARY SCHOOL TEACHERS' PERCEPTIONS OF AND PRACTICES IN THE SELECTION AND DEVELOPMENT OF ENGLISH LEARNING MATERIALS
}

\author{
Nurdin Noni \\ FBS Universitas Negeri Makassar \\ email: nurdinnoni@yahoo.com
}

\begin{abstract}
This study aims to describe: (a) teachers' profiles, (b) teachers' perceptions of the use of learning materials, and (c) practices in the selection and development of English learning materials by primary school teachers in Makassar City. The study used the descriptive method by involving primary school teachers of English. The sample consisted of 15 primary school teachers of English, randomly selected from two clusters, namely the city center and the suburb. The data were collected using a questionnaire. The results and discussion include the English teachers' profiles, perceptions of, and practices in the selection and development of English learning materials for primary schools. In general, it can be concluded that the perceptions of primary school teachers of English are in line with their practices in the selection and development of learning materials.
\end{abstract}

Keywords: perception and practices, selection and development of English learning materials

\section{PERSEPSI DAN PRAKTIK GURU SEKOLAH DASAR DALAM PEMILIHAN DAN PENGEMBANGAN MATERI PEMBELAJARAN BAHASA INGGRIS}

\begin{abstract}
Abstrak
Penelitian ini bertujuan mendeskripsikan: (a) profil guru, (b) persepsi guru terhadap penggunaan materi pembelajaran, dan (c) praktik pemilihan dan pengembangan materi pembelajaran bahasa Inggris oleh guru sekolah dasar di Kota Makassar. Metode yang digunakan adalah metode deskriptif dengan melibatkan 15 guru bahasa Inggris sekolah dasar yang dipilih secara acak dari dua klaster, yakni pusat kota dan daerah pinggiran kota. Data dikumpulkan dengan menggunakan angket. Hasil dan pembahasan meliputi profil guru bahasa Inggris, persepsi, dan praktik pemilihan dan pengembangan bahan ajar bahasa Inggris untuk sekolah dasar. Secara umum dapat disimpulkan bahwa persepsi guru bahasa Inggris sekolah dasar memiliki kesesuaian dengan praktik yang mereka lakukan dalam pemilihan dan pengembangan bahan ajar.
\end{abstract}

Kata kunci: persepsi dan praktik pembelajaran, pemilihan dan pengembangan materi pembelajaran

\section{INTRODUCTION}

There are several factors that need to be considered in the context of learning English as a foreign language, such as teachers, students, learning materials, and setting and time context. Teachers intended in this article are those teaching at the primary school level. The teachers should meet several requirements, such as relevant qualifications and sufficient 
competence consisting of professional, pedagogical, social, and personal competence (Permendiknas No. 16 Tahun 2007).

However, Sikki, et al. (2013) found that "the teachers'competence still needs improvement. Data from their research indicated that more than $50 \%$ of the teachers had low and fair professional competence, and $90 \%$ had low and fair pedagogical competence. Furthermore, they also found that there were three types of primary school English teachers in Indonesia, namely (i) classroom teachers who never attended English teaching college, (ii) English teachers who attended English teaching college but had no experience working with children, and (iii) teachers who had English background and experience of working with children" (pp. 144-145).These findings are also supported by the finding of Sukamerta (2011) which shows that most of the teachers who taught English at primary schools did not have adequate English language competence and skills in order to be teachers of English as a foreign language at primary school, since some of them did not have English education background (p. 260).

In the context of English language learning at primary school level in Indonesia, there are some requirements that need to be considered. In this regard, Musthafa (2010) elaborates five pillars that English teachers should know"(i) the children they teach, (ii) how children learn, (iii) how children learn language, (iv) how Indonesian children learn English as a foreign language, and (v) how to facilitate children to learn English as a foreign language in Indonesia" ( $p$. 120). It can be concluded that students should be the primary consideration to be understood by a teacher of English. Indonesian children certainly have their own unique characteristics which may be affected by cultures and habits occurring in their environment.
The factors mentioned above should also be considered by teachers to choose and decide, even to develop teaching materials they will use. Chien (2003) in his study at primary school level reported that integrating English into subject matters or courses could motivate students to learn better. Moon (in Suyanto, 2004) articulates that learning material is an important source for teachers in helping students to learn English. Learning materials for primary school students can be in the forms of textbooks, student work sheets (LKS), story books, dialogue tapes, brochures, pictures, posters or other real objects. As mentioned in the Attachment of the Minister of Education Decree No. 24 Year 2007, the minimum standard for facilities includes learning resources consisting of textbooks, guidebook for educator, supplementary books, reference books, and other learning resources, such as magazines, newspaper, globe, maps, and CDs (Permendiknas No. 24 Tahun 2007). Textbooks are compulsory books used at elementary and secondary schools or higher education institutions which contain learning materials written in compliance with national standard of education (Permendiknas No. 2 Tahun 2008). They are the main learning resources to achieve basic competence and core competence (Peraturan Pemerintah Nomor 32 Tahun 2013).

In this case, the most important one is not the material but how the material is used to help students learn the language. In this regard, Suyanto (2004) conveys that there are quite many English teaching materials for primary schools available in the market, but only a few meet the requirements to be used as a textbook for students in the classroom. Therefore, teachers must be able and skillful to select textbooks by considering the appropriateness of objectives, content, language, and level of difficulty for students. Breen and Candlin (1987) 
propose a guide in which they pose some initial questions as to the usefulness of materials, such as "what are the aims and content of the materials?, What do they require learners to do?, what do they require you, as a teacher, to do?, and what function do they have as a classroom resource?" In other words, the teachers should have knowledge about criteria in selecting teaching materials and be able to apply them in deciding teaching materials that they will use in their class. For the textbooks of compulsory subjects, BSNP (National Education Standards Board) is given task to evaluate their feasibility in terms of content, language, presentation, and printing quality (Pusat Kurikulum dan Perbukuan Kemdikbud).

According to Tomlinson (2013, p. 21), materials evaluation is a procedure that involves measuring the value (or potential value) of a set of learning materials. It involves making judgements about the effect of the materials on the people using them and it tries to measure some aspects, such as the appeal of the materials to the learners, the credibility of the materials to learners, teachers and administrators, the validity of the materials, the reliability of the materials, the ability of the materials to interest the learners and the teachers, the ability of the materials to motivate the learners, the value of the materials in terms of short-term learning, the value of the materials in terms of long-term learning, the learners' perceptions of the value of the materials, the teachers' perceptions of the value of the materials, the assistance given to the teachers in terms of preparation, delivery and assessment, the flexibility of the materials, the contribution made by the materials to teacher development, and the match with administrative requirements (e.g. standardization across classes, coverage of a syllabus, preparation for an examination).

Mukundan, et al. (2011) suggest that before teachers of English make decisions on the materials they select for their target students, they need to take a wide range of criteria into consideration. The criteria are mainly divided into two general categories, namely general attributes and learning-teaching content. The first category is further broken-down into five subcategories, i.e. relation to syllabus and curriculum, methodology, suitability to learners, physical and utilitarian attributes, and supplementary materials. The second category includes general (i.e., task quality, cultural sensitivity, as well as linguistic and situational realism), listening, speaking, reading, writing, vocabulary, grammar, pronunciation, and exercises.

To design and select effective learning materials, Howard and Major (2005) propose clues that English learning materials should: (i) be contextual, (ii) stimulate interaction, (iii) encourage students to develop their skills and learning strategies, (iv) provide chances for integrated language use, (v) be authentic, (vi) be interesting, (vii) have appropriate instructions, and (viii) be flexible (pp. 104-107).

In line with the explanation above, Cunningsworth (in Tok, 2010) suggests that "teachers should thoroughly select learning materials or textbooks which reflect the students' learning needs and objectives, method and values of teaching program" (p. 509). The selection of learning materials can help teachers acquire useful, accurate, systematic, and contextual insights about the nature of learning materials and textbooks. Besides, teachers should be able to adapt and / or design learning materials containing culture values and local wisdom.

In designing local culture-based teaching materials, it is suggested that culture elements that can facilitate and accelerate the English learning be incorporated. This is intended to nurture the values contained in the local culture 
such as religious, moral, and in particular national values for learners. English teachers should be able to develop English language teaching material in order to incorporate the elements of local culture into them so that the local and global culture can be synergized through English teaching at primary schools (Sukamerta, 2011, p. 262).

This study focuses on the use of teaching materials at primary school, especially those related to teachers' perceptions of and practices in the selection and development of English language learning materials in primary schools of Makassar. Three questions would be answered and analyzed in this study, namely: (i) how is the profile of primary school English teacher in Makassar? (ii) how is the perception of primary school English teachers toward the use of English language learning materials at primary schools of Makassar?, and (iii) how are the practices of teachers in selecting and developing English learning materials at primary schools of Makassar?

\section{RESEARCH METHOD}

This research used quantitative descriptive method. This method was used to describe the characteristics of the object being studied, especially in terms of perceptions of and practices of primary school teachers in selecting and developing English language learning materials of primary schools in Makassar. This study used cluster-random sampling technique. The clusters were suburban and city center areas. From these two clusters, ten primary schools were selected randomly, six schools in city center area and four schools in suburban area. The study involved all teachers of English from the selected schools as respondents, namely 15 people.

The instrument used in this study was a questionnaire containing three components, namely the profile of teachers, teachers' perception towards the use of English learning materials in primary schools in Makassar, and practices of selecting and developing English language learning materials by primary school teachers of English in the city of Makassar. At the end part of the questionnaire, the researcher provided open questions which included the textbooks used, the constraints experienced in the implementation of books/teaching materials used, and suggestion in relation to the implementation of textbooks/ teaching materials used. Data were analyzed through descriptive analysis, particularly frequency and percentage.

\section{RESULTS AND DISCUSSIONS Profile of Primary School English Teachers}

Respondents of this study consisted of fifteen English teachers in ten primary schools in the city of Makassar. Their ages ranged from $31-40$ years (64\%) and the rest were 30 and below. This means that they are still in a very productive and energetic age. All of the teachers were from undergraduate education background (S1), with $62.5 \%$ from English education and $37.5 \%$ from English Literature. Their qualifications and education that they gained were actually quite adequate to the task of teaching English in primary schools and complied with the academic qualification (Permendiknas No. 16 Tahun 2007). In addition, they had also been following activities related to capacity building in English, such as workshops, seminars/conferences, and training.

Teaching experiences that they had were also quite sufficient. The data showed that $45 \%$ have been teaching between 6-10 years, 27\% for 3-5 years, and respectively $18 \%$ and $9 \%$ for more than 10 years and for 1-2 years. However, their employment status was dominantly non-government teachers (91\%) compared to the civil servant or permanent position $(9 \%)$. Grades or level of students that 
they taught scattered from grade 1 to grade 6 , but dominantly grades 4,5 , and 6 . Furthermore, the average number of pupils in one class they taught varied, but they could be classified into two groups, namely 31 students or more (55\%) and 30 students or less ( $45 \%)$.

\section{Teachers' Perception on the Use of English Learning Materials in Primary Schools in Makassar}

In line with the curriculum relevance, the data showed that $45 \%$ of respondents agreed that the English learning materials used in primary schools were in accordance with the curriculum, while $36 \%$ disagreed and the rest (18\%) strongly agreed to the statement. This means that most teachers had the perception that the English language learning materials in primary schools were relevant with the existing curriculum. However, the respondents stated that they often found some parts of the material which were not relevant with the curriculum. The data showed that approximately $60 \%$ and $10 \%$ of the respondents agreed and strongly agreed to the statement, and the rest $(30 \%)$ disagreed.

Other data showed that $45 \%$ and $18 \%$ of respondents disagreed and strongly disagreed to the statement that they did not require additional learning materials because they considered that the existing textbooks or learning materials already met the coverage of curriculum, 27\% agreed and only $9 \%$ stated 'strongly agree'. This means that most respondents needed additional materials to supplement their teaching activities.

The results of analysis above can be further elaborated that in general teachers had the perception that the textbooks or teaching materials used in primary schools over the years, particularly in the city of Makassar, were already relevant with the curriculum. This is already in line with what Tomlinson (2013, p. 98) states that materials should be clearly linked to the curriculum they serve. Howard and Major (2005) also suggest that teachers as evaluators should be able to determine how closely the content of the resource matches and supports the prescribed learning outcomes of the curriculum. However, certain parts were claimed irrelevant. This is consistent with other findings indicating that most teachers still required supplementary materials to meet the learning needs of students. Of course, there were two choices that could be opted by teachers, namely searching relevant supplementary materials which can be obtained from various sources, including authentic materials, or even taking the opportunity to develop their own supplementary teaching materials in order to meet the students' learning needs without neglecting the goals of the curriculum. Therefore, teachers need to equip themselves with knowledge and skills of teaching material development.

Based on the aspects relating to students, the result showed that $64 \%$ and $18 \%$ of respondents agreed and strongly agreed to the statement that the difficulty level of English language teaching materials were in accordance with the student competence, the rest $(18 \%)$ disagreed. This showed the respondents' positive standpoint indicating that the teaching materials used had already been appropriate to apply in their class they teach.

Other data showed that $64 \%$ and $36 \%$ of respondents agreed and strongly agreed that the materials being taught were exciting. This is consistent with other findings, in which there were successively $73 \%$ and $18 \%$ of the respondents who agreed and strongly agreed that the students were excited to learn English, and the rest $(9 \%)$ disagreed. This means that the students were fond of the teaching materials used. This needs further studies on the aspects of the learning 
materials that appeal students' interest. The favorable thing was that students were interested in learning English.This becomes an initial basis to further enhance their interest through more interesting teaching materials of various aspects. As indicated in the previous part, Howard and Major (2005) state that effective learning materials should be interesting, stimulating interaction, and encouraging students to develop their skills and learning strategies.

There were $55 \%$ and $18 \%$ of respondents who agreed and strongly agreed to the statement saying that "I often find that there are parts of the materials which are not suitable with students' competence". Only $27 \%$ disagreed to the statement. For the statement about the suitability of the topics discussed in the teaching materials with the needs of each level, it was found that $72 \%$ agreed and $27 \%$ disagreed.

The data above implies that there were certain aspects of the teaching materials which were not yet in accordance with the level of student competence. This also indicated that teachers were required to provide supplementary teaching materials or even develop their own teaching materials to fill the gap of the intended aspects. Similarly, the topics of discussion were claimed to be appropriate by most of respondents, however there was still a significant number of respondents who claimed them inappropriate. Therefore, teachers should involve students in deciding the topics that will be discussed at the beginning of the semester or school year. Breen and Candlin (1987) state that the more we involve them in exploring learning materials with us the more likely it is that they will want to refine the materials for their use. Learners are the main consumers of materials. Therefore, teaching materials should be produced in harmony with their learning priorities and their diverse ways of learning a language.
In relation to the result of the content of learning materials, the data showed that $55 \%$ and $9 \%$ of the respondents agreed and strongly agreed that the time allocation of the teaching load for each session was already proportional. Only $36 \%$ of them disagreed. For the statement regarding whether all English language skills had already been covered in the teaching materials used, the data showed that $82 \%$ of the respondents agreed and the rest (18\%) disagreed. The same result $(82 \%$ and $18 \%$ ) also occurred to the statement that all instructions in the teaching materials were already clear for students.

For the question regarding whether the images or illustrations used in teaching materials helped students in learning English, the data showed that $73 \%$ of respondents answered 'agree' and 27\% answered 'strongly agree'. Conversely, to the question of whether the images or illustrations in teaching materials were excessive, the result showed that $73 \%$ of respondents disagreed, and the rest $18 \%$ and $9 \%$ answered 'agree' and 'strongly agree'. Furthermore, for the type and size of the font used in the instructional materials, $91 \%$ and $9 \%$ said it was appropriate and very appropriate with the students' age level.

The data analysis above implies that most of the respondents had the perception that the load of each material for each session was already proportional to the time that had been allocated. Furthermore, the data also showed that all English language skills, namely listening, speaking, reading and writing were included in the teaching materials. However, there was no evidence that reveals the proportion of the language skills as well as the language elements, especially vocabulary.

Another aspect of the content of the learning material investigated was instructions or directions, which according to the teacher's perception were quite clear. However, it was not clarified 
whether the instructions were given in either English or Indonesian. Actually, whatever the language they use, clarity is very important in order to be easily understood by both teachers and students, so that the tasks to be done by the students are also clear. Ideally instructions should be easier to understand, and not more difficult than the content of the lesson or task for students to complete.

Regarding the pictures and illustrations displayed in the learning materials, all of the respondents considered them quite helpful for students to learn English. This means that the illustrations and images were relevant to the topics presented and probably to the students' age level. This is important because primary school students need more visualizations. In line with this, Hill (2013) reported that a majority of pictures included in coursebooks which are used for language purposes tend to concentrate on low-level language skills related to basic language manipulation. The above data also showed that most respondents considered that the quantities of pictures or illustrations in the teaching materials were quite proportional.

Several studies have proven the benefits of visualization, especially pictures and illustrations in English learning. Elmen (2013), for example, found that students had a positive attitude towards the use of images in English class. They stated that the use of images in English language learning were fun and beneficial, and even increased their interest (p. 21). This is supported by Canning (2001) who found that $93 \%$ of the students previously given pictures were capable of describing objects well, whereas only $52 \%$ of them not previously given pictures were able to describe the objects.

In addition to pictures or illustrations, type and font size should also be considered. The students should be familiar with the type of font used in the textbooks or learning materials in order that they can easily read them. Besides, the font size should also be clear enough for students to read. The data indicated that all respondents considered that the type and size of fonts used in the teaching materials were appropriate with the age level of students.

This part ends with a question about the decision of English language learning materials selected in each class at the primary school level. The data obtained showed that $82 \%$ and $18 \%$ of respondents agreed and strongly agreed that teaching materials selected to be used in a class were decided by the teachers who taught the class. This indicates that the teachers of English at primary school level had the perception that English language teaching materials should be decided by the teachers themselves. This perception is very reasonable because they are the ones who know their students' learning needs, including their students' prior knowledge in English. In this regard, teachers are demanded to evaluate learning materials or textbooks of English to suit students' needs and curriculum objectives. According to Sheldon (1988), textbook evaluation is needed for two reasons, namely helping teachers in making decisions on selecting applicable textbook and familiarizing teachers with its strengths and weaknesses for the sake of learning materials adaptation.

\section{The Practices of English Learning Material Selection and Development in Primary Schools in Makassar}

This section covers the results and discussion on the teachers' practices in selecting and developing English language learning materials at primary school level. In terms of textbook selection, the Minister of Education Decree regulates that the textbooks of all courses used in basic and secondary schools are selected by educators meeting of school level. The textbooks must have been eligibly 
approved by the Minister. For local content courses, the textbooks must have been approved by the governor (Permendiknas Nomor 2 Tahun 2008).

The analysis showed that $91 \%$ of respondents answered 'agree' and 9\% answered 'disagree' to the statement "I myself decide the English textbook or teaching materials that I use in my class". Furthermore, $45 \%$ disagreed to the statement that the textbooks or teaching materials used in the classes depended on those available in their school. The rest $(36 \%$ and $18 \%$ ) successively answered 'agree' and 'strongly agree'.

Based on the results above, it could be explained that in practice most teachers chose their own English textbooks or teaching materials for their class. This means that they still ignored the regulation as mentioned above in which the textbooks to be used at schools should be decided in school level meeting (Permendiknas Nomor 2 Tahun 2008).This finding is consistent with their perception of the same thing. However, this is somewhat different from another finding in which a half of the respondents still depended on the textbooks available at school. Yet, the textbooks could possibly be relevant with the curriculum and class conditions.

In relation to the relevance to curriculum, $45 \%$ and $18 \%$ of the respondents agreed and strongly agreed to select textbooks or teaching materials by always considering the issue of the curriculum relevance, while only $36 \%$ disagreed. Besides, $64 \%$ and $27 \%$ agreed and strongly agreed to consider the suitability of the competence of students they taught. Another finding showed that every textbook that would be used was pretested to students to know their initial competence. This was proved by the data which showed that $73 \%$ and $18 \%$ of the respondents agreed and strongly agreed to the referred statement. Only $9 \%$ disagreed.
The presentation of data above reveals that most respondents considered the relevance of curriculum in selecting English textbooks or teaching materials (Mukundan, et al., 2011; Tomlinson, 2013; and Howard and Major, 2005). On the other hand, there were still a significant number of respondents who did not have such consideration. In practice, many teachers did not assess or try to understand the curriculum before they determined the textbooks or teaching materials they wanted to use. They, even, believed that the textbooks were already relevant since they were written or notified "based on the curriculum..." on the textbook cover. For conformity with the ability of students, it seemed all respondents considered it in choosing books or teaching materials. In terms of the appropriateness with students' competence, all respondents took it into account in selecting textbooks or teaching materials. The interesting thing is that most respondents did pre-test to obtain a picture about the initial understanding of their students. This is a good practice in order to make a proper lesson plan for their students.

In relation to the content of learning materials, the analysis showed that $73 \%$ and 9\% answered 'agree' and 'strongly agree' to the statement that they always considered the suitability of pictures or illustrations in selecting textbooks or teaching materials. The rest $(18 \%)$ answered'disagree'. The same thing happened to the statement about the suitability of font size in selecting textbooks or teaching materials. The analysis showed that $73 \%$ answered 'agree', and the rest answered 'disagree'.

Other results showed that $73 \%$ and $27 \%$ of respondents agreed and strongly agreed to the statement that in selecting textbooks or teaching materials, they prioritized the language skills, namely reading, speaking, listening and writing. Furthermore, 36\% 
and $27 \%$ answered 'strongly agree' and 'agree'for the statement that in selecting textbooks or teaching materials they emphasized more on vocabulary; the rest $(36 \%)$ answered 'disagree'. For the question of whether in selecting textbooks or teaching materials they gave more priority on the grammar, $64 \%$ and $9 \%$ answered 'agree' and 'strongly agree', and $27 \%$ disagreed. For the statement about their understanding on the principles and criteria for selecting textbooks or teaching materials, it was found that there were $73 \%$ and $27 \%$ of the respondents who stated 'understood' and 'did not understand'. This means that more teachers could choose appropriate textbooks or teaching materials for their students.

The data above present the teachers' practice in selecting learning materials based on content criteria (Breen and Candlin, 1987; Mukundan, et al., 2011; and Pusat Kurikulum dan Perbukuan Kemdikbud). It can be further elaborated that the teachers in selecting their teaching materials always considered the appropriateness of picture or illustration as well as the font size. This is in line with their perceptions of those who assumed that pictures or illustrations satisfactorily helped students in learning (Sheldon, 1988). In conjunction with the language elements and skills, they in selecting textbooks or teaching materials successively emphasized more on the four language skills, followed by grammar and vocabulary. This finding indicated that the vocabulary got less attention than the language skills and grammar. It is in contrary that vocabulary is very important to be enriched for children to support their mastery of language skills.

With respect to the development of teaching materials, the data showed that $64 \%$ and $27 \%$ of respondents agreed and strongly agreed to the statement that they often prepared additional materials to meet the students' learning needs in class, and the rest $(9 \%)$ disagreed. In contrast, there were $64 \%$ and $18 \%$ who disagreed and strongly disagreed to the statement that they did not need to prepare additional teaching materials because they felt that the existing textbooks or teaching materials were already sufficient to meet the students learning needs. Only $9 \%$ each strongly agreed and agreed.To the statement that they developed their own teaching materials because they felt there was no textbook relevant with the curriculum or suitable with the students' learning needs, $60 \%$ agreed and $40 \%$ disagreed.

In the question about whether they sometimes searched for teaching materials in the internet, $64 \%$ and $27 \%$ of respondents answered 'agree' and 'strongly agree', and the rest (9\%) answered 'disagree'. Furthermore, for the question about whether they sometimes used a laptop or computer in teaching, $82 \%$ and $9 \%$ answered 'agree' and 'strongly agree' and 9\% answered 'disagree'.

Based on the results above, it could be explained that all respondents often prepared supplementary materials, which means that the existing textbooks or instructional materials were not enough to meet all students' learning needs or even the curriculum demands. Some teachers even also developed their own teaching materials to meet the learning objectives that they had prepared. In addition, they also utilized internet facilities to obtain the necessary teaching materials. In the implementation of learning in the classroom, they also used laptop or computer. This is a good practice in the implementation of selecting and developing English language teaching materials. These processes are actually the effort to adapt the teaching materials in order to be more relevant. Saraceni (2013) points out that in an attempt to make the materials more relevant and useful for their users, the conventional approach 
to materials adaptation generally relates to a number of changes to the materials, such as, the process of deleting, reordering or adding. Adapting materials is an inevitable process as it is always carried out as part of classroom practice.

The questionnaire of this study ends with three items of open questions. The first item concerns with the textbooks or teaching materials used. The result showed that in general the teachers used textbooks available in the market.The second item is about the constraints experienced in implementing the textbooks or teaching materials. For this issue, the respondents stated that the main obstacle found was that the vocabulary used in the textbooks was unfamiliar or too high for low-grade students. They also argued that the textbooks used did not suit the ability of primary school students. Another obstacle was the lack of teaching aids at school. This resulted in the students to slowly understand and comprehend the lessons delivered by the teacher. The third item is suggestion. The teachers expected that the textbooks or teaching materials were available at school by considering the suitability with students' competence for each level.

\section{CONCLUSION}

There are two important issues discussed in this research article, namely the teachers'perceptions of and practices in selecting and developing English language learning materials for primary schools in Makassar. In general, the results of both issues are identical. Overall, the perception of English teachers at primary level in Makassar was that the English textbooks or teaching materials of primary schools were appropriate, particularly in terms of curriculum relevance, students' competence, proportion of the load of each material and the time allocation, students' interest, coverage of language skills, clarity of instructions, font type and size, and pictures/illustrations. However, some specific parts of the textbooks or instructional materials were not yet appropriate. Therefore, they also considered the need for adaptation and further development of teaching materials in order to bridge the gap of the students' English learning needs.

In relation to the practices of selecting and developing teaching materials, the teachers themselves decided their own textbooks or teaching materials that they wanted to use in their class, by taking into account the aspects of curriculum relevance, student's competence, pictures/ illustrations, font size, language skills, vocabulary, and grammar. In addition, they also prepared supplementary materials to meet the students' English learning needs. Another interesting thing was that they sometimes used internet facilities to search for supporting teaching materials and even used laptop or computer in delivering their teaching.

\section{ACKNOWLEDGEMENTS}

The researcher would like to express his appreciation to the Director of Postgraduate Studies of Universitas Negeri Makassar who financially supported this research. He is also grateful to Ibu Masnijuri, S.Pd., M.A. and Team for their valuable assistance in collecting data at schools. Finally, he would like to thank all teachers of English for their participation as respondents of this research.

\section{REFERENCES}

Breen, M. \& Candlin, C. 1987. "What Materials? A Consumer's and Designer's Guide. In L. E. Sheldon (ed.). ELT Textbook and Materials: Problems in Evaluation and Development. ELT Documents 126. (pp. 13-28) Oxford: Modern English Publications in association with The British Council.

Canning, Christine. 2001. "Visuals and Language Learning: Is There 
a Connection?"The Weekly Column. Center for Excellence in Applied Research and Training (CERT College), Higher Colleges of Technology-Abu Dhabi. http://www.eltnewsletter.com/back/ Feb2001/art482001.htm

Chien, Grace Chin-Wen. 2003. “Integrating English into an Primary School Life Course." The Internet TESL Journal, Volume 9, Number 12, December. Retrieved from iteslj.org/Articles/ Chien-Integrating.html

Elmén, Isak. 2013. "Pictures as an Aesthetical Tool in English Language Teaching: An Experimental Study." Department of Language, Literature and Intercultural Studies, Faculty of Arts and Social Sciences, Karlstads Universitet.Retrieved from http:// kau.diva-portal.org/smash/get/ diva2:698251/FULLTEXT01.pdf

Hill, David A. 2013. "The Visual Elements in EFL Coursebooks."In Brian Tomlinson (ed.). Developing Materials for Language Teaching (Second Edition). (pp. 157-166). London: Bloomsbury.

Howard, J. and Major, J. 2005. "Guidelines for Designing Effective English Language Teaching Materials." Proceedings of the Ninth Conference of Pan-Pacific Association of Applied Linguistics, pp. 101-109. Retrieved from http://www.paaljapan.org/ resources/documents.html

Mukundan, Jayakaran, et al. 2011. "Developing an English Language Textbook Evaluation Checklist." Contemporary Issues in Education Research, Volume 4, Number 6, pp. 21-27.

Musthafa, Bachrudin. 2010. “Teaching English to Young Learners in Indonesia: Essential Requirements. "Educationist,Volume 4, Number 2, pp. 120-125. Retrieved fromhttp:// file.upi.edu/Direktori/JURNAL/ EDUCATIONIST/Vol._IV_No._2-
Juli_2010/07_Bachrudin_Musthafa. pdf

Peraturan Pemerintah Nomor 32 Tahun 2013 tentang Perubahan atas Peraturan Pemerintah Nomor 19 Tahun 2005 tentang Standar Nasional Pendidikan.

Permendiknas (Peraturan Menteri Pendidikan Nasional) Republik Indonesia Nomor 2 Tahun 2008 tentang Buku.

Permendiknas Republik Indonesia Nomor 16 Tahun 2007 tentang Standar Kualifikasi Akademik dan Kompetensi Guru.

Permendiknas Republik Indonesia Nomor 24 Tahun 2007 tentang Standar Sarana PrasaranaSekolah/Madrasah Pendidikan Umum.

Pusat Kurikulum dan Perbukuan, Badan Penelitian dan Pengembangan, Kementerian Pendidikan dan Kebudayaan. Penilian Buku Teks Pelajaran. Retrieved fromhttp://puskurbuk. kemdikbud.go.id/web13/buku-teks. html.

Saraceni, Claudia. 2013. Adapting Courses: A Personal View. Developing Materials for Language Teaching (Second Edition). London: Bloomsbury.

Sheldon, Leslie. E. 1988."Evaluating ELT Textbooks and Materials." ELT Journal, Volume 42, Number 4.

Sikki, Endang Asriyanti Amin, Asfah Rahman, Arifuddin Hamra, and Nurdin Noni. 2013. "The Competence of Primary School English Teachers in Indonesia." Journal of Education and Practice. Volume 4, Number 11, pp. 139-145.

Sukamerta, Made. 2011. “Implementasi Kebijakan Pembelajaran Bahasa Inggris pada Sekolah Dasar di Kota Denpasar."Tesis. Denpasar: Universitas Udayana.

Suyanto, Kasihani, E. 2004. Pengajaran Bahasa Inggris di Sekolah Dasar: Kebijakan, Implementasi, dan Kenyataan. Pidato Pengukuhan Guru Besar. 
Tok, Hidayet. 2010. “TEFL Textbook Evaluation: From Teachers' Perspectives." Educational Research and Review, Volume 5, Number 9, pp. 508-517. Retrieved fromwww. academicjournals.org/journal/ERR/ edition/September_2010

Tomlinson, Brian. 2013. “Developing Principled Frameworks for Materials
Development," In Brian Tomlinson (ed.). Developing Materials for Language Teaching (Second Edition). (pp. 95-118). London: Bloomsbury.

Tomlinson, Brian. 2013. "Materials Evaluation." In Brian Tomlinson (ed.). Developing Materials for Language Teaching (Second Edition). (pp. 21-48) London: Bloomsbury. 